International Journal of Life Sciences
Available online at http://sciencescholar.us/journal/index.php/ijls
Vol. 2 No. 2, August 2018, pages: $1 \sim 11$
e-ISSN: 2550-6986, p-ISSN: $2550-6994$
http://dx.doi.org/10.29332/ijls.v2n2.114

\title{
Nutrient Digestion and Body Weight Gain of Balinese Cows Getting Basic Ration of Spear Grass and Rosewood Leaves Supplemented with Falcata Tree Leaves
}

\author{
Stefanus Sio ${ }^{a}$, Hilarius Yosep Sikone ${ }^{b}$, Charles Asar Usboko ${ }^{c}$ \\ Article history: Received 10 December 2017, Accepted in revised form 20 March 2018, Approved 30 March 2018, \\ Available online 2 May 2018
}

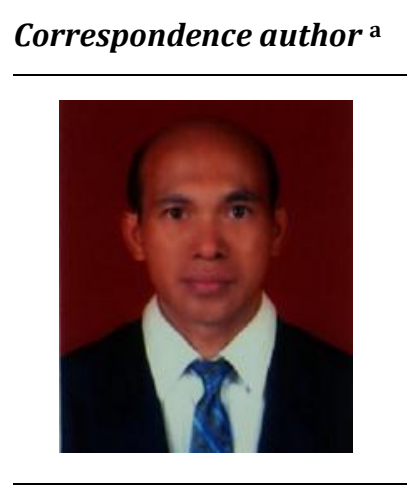

Keywords

Balinese Cows;

Digestion;

Rosewood Leaves;

Falcata Tree Leaves;

Spear Grass;

\begin{abstract}
A study had been conducted to find out nutrient digestion and body weight gain of Balinese cows getting a basic ration of spear grass and Rosewood leaves supplemented with Falcata tree leaves. The study was using complete randomized block design with 4 ration treatments and 3 times repetition. Each repetition was using three Balinese cows. The weights of cows being used were in the range of 83-181 kg. Basic ration being given was arranged based on the percentage of dry ingredients namely: $80 \%$ of spear grass $+20 \%$ of rosewood leaves (A), $80 \%$ of spear grass $+20 \%$ of rosewood leaves $+10 \%$ of falcata tree leaves (B), $80 \%$ of spear grass $+20 \%$ of rosewood leaves $+15 \%$ of falcata tree leaves (C), and $80 \%$ of spear grass $+20 \%$ of rosewood leaves $+20 \%$ of falcata tree leaves (D), The variables being measured were: nutrient digestion and body weight gain. The result of the study showed that with the administration of $20 \%$ falcata tree leaves in the basic ration, it differed significantly $(\mathrm{P}<0.05)$ in increasing nutrient digestion and daily weight gain. The result of the study concluded that with the administration of falcata tree leaves in the basic ration of spear grass and rosewood leaves capable to increase nutrient digestion so that bacteria would optimally increase the utilization of fodder and led to a high weight gain of Balinese cows.
\end{abstract}

e-ISSN : 2550-6986, p-ISSN : 2550-6994@ Copyright 2018. The Author. SS Journals Published by Universidad Técnica de Manabí. This is an open-access article under the CC BY-SA 4.0 license (https://creativecommons.org/licenses/by-sa/4.0/) All rights reserved.

a Faculty of Agricultural, University of Timor

b Faculty of Agricultural, University of Timor

c Faculty of Agricultural, University of Timor 


\section{Contents}

Abstract

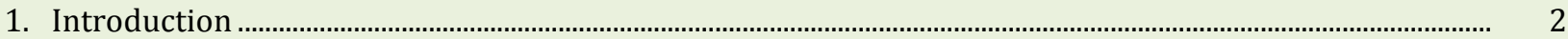

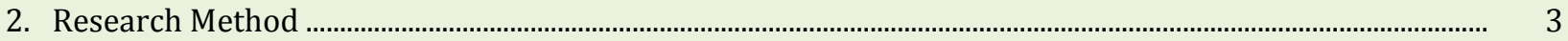

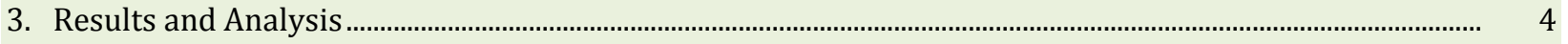

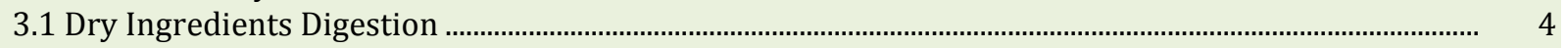

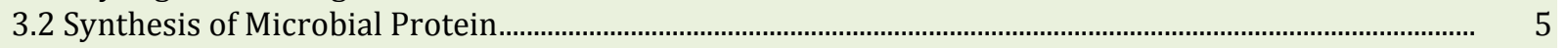

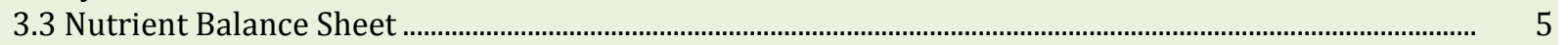

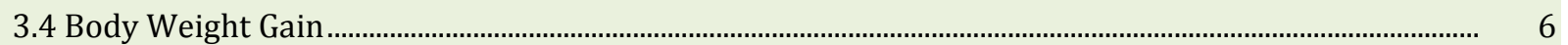

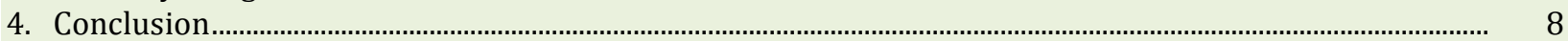

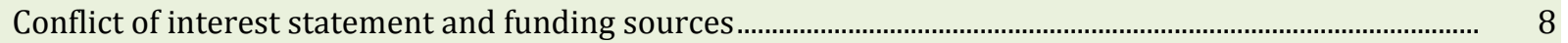

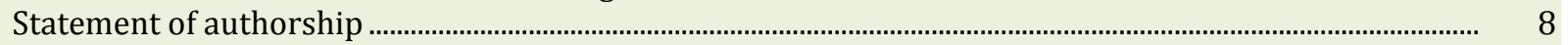

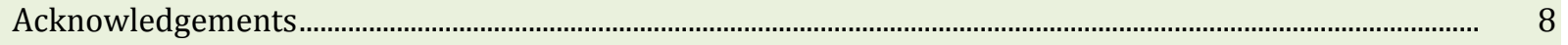

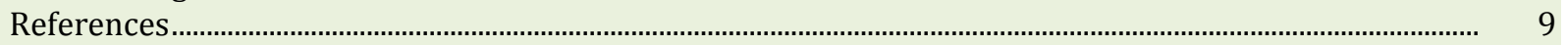

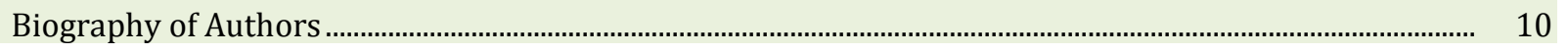

\section{Introduction}

Protein requirement originated from the animal for Indonesian people from day to day increasingly growing. This is in line with the increase of population growth, income and awareness of the people. Along with the increase in the needs for animal protein, so it demands the increase in meat production through the effort to improve cattle population. One of Indonesian germplasm which is reliable to increase meat production is Balinese cow. Guntoro (2002) stated that Balinese cow was one of beef cattle which could contribute best to meat by $29 \%$ compared to other beef cattle being cultivated in the country.

Cultivation of Balinese cows in an effort to increase productivity, primary attention is directed more to the growth. The growth of Balinese cows is affected by a various factor, among others is the availability of animal feed both qualitatively and quantitatively. Oka et al. (2012) stated that cattle productivity, especially for growth and production, $60 \%$ were influenced by feed, nutrition content, and technology to formulate the ration.

East Nusa Tenggara in general and western Timor island in particular, is potential to develop Balinese cows as beef cattle. It is supported by a resource like grazing area: 832,228 ha (Leburaya, 2012), availability of various forage feeds among others family of grass, Leguminosae, trees, an appropriate human resource as well as government policy to make NTT as cattle province.

The type of natural grass which predominantly grows and is potential as forage feed in Timor island among others is spear grass (Heteropogon contortus), meanwhile, the type of tree is rosewood. Speargrass and rosewood are potential as forage feed, but both materials have low crude protein content in which spear grass has only 5.90\% (Sio, 2016) and rosewood leaves have crude protein of 5.9\% (Sio, 2017). Speargrass and rosewood leave with low crude protein if given to Balinese cow can obstruct the cattle growth which results in low weight gain. It is because the low crude protein in spear grass and rosewood leaves will lead to rumen microbes not able to work optimally to digest feed, so that rumen fermentation is not optimal to produce rumen metabolites.

Regarding administration of spear grass and rosewood leaves for Balinese cow, in order to get maximum growth then it needs to be supplemented with falcata tree leaves. Falcata tree is a Leguminosae plant, the tree that thrives in both summer and rainy season, the leaves are not falling and have high crude protein content at $20.68 \%$ (Sio, 2017). Supplementation of falcata tree leaves is intended to cover the lack of crude protein from spear grass and rosewood leaves so that it is able to improve the activity of rumen microbes to digest feed in order to produce rumen metabolites as the source of energy for cattle growth. The utilization of falcata tree leaves as forage feed for Balinese cows in NTT in general and particularly in Timor island is not carried out optimally. In addition, there is no research data regarding the utilization of falcata tree leaves as the feed for Balinese cows. In connection with the above mentioned then a study has been conducted with the title of "Nutrient digestion and body weight gain of Balinese cows getting a basic ration of spear grass and rose-wood leaves supplemented with falcata tree leaves (Paraserianthes falcataria L.)". 
2. Research Method

Material

The tools being used were: electronic scale with sonic scala AE12 brand, the capacity of $2000 \mathrm{~kg} \times 0.5$ $\mathrm{kg}$, hanging scale with a capacity of $50 \mathrm{~kg}$, sitting scale, sickle, knife, machete, bucket, clamp cage, shovel, sack. The material being used including Balinese cow, spear grass, rosewood leaves, falcata tree leaves and drinking water.

\section{Method}

Experimental Design

The study used randomized block design (RAK) consisted of 4 ration treatments and 3 groups of cattle weight as repetition. The cattle being used numbering 12 cows with an average weight in group I = $90 \mathrm{~kg}$, in group II = $142 \mathrm{~kg}$ and in group III = $171 \mathrm{~kg}$. Those four ration treatments being used were:

a) $80 \%$ of spear grass $+20 \%$ of rosewood leaves

b) $80 \%$ of spear grass $+20 \%$ of rosewood leaves $+10 \%$ of falcata tree leaves

c) $80 \%$ of spear grass $+20 \%$ of rosewood leaves $+15 \%$ of falcata tree leaves

d) $80 \%$ of spear grass $+20 \%$ of rosewood leaves $+20 \%$ of falcata tree leaves

\section{Location and Time of Study}

The research was conducted at stock farmer group of Ulnaet Tuan, Village of Letmafo, District of Insana Tengah, Regency of TTU, Province of NTT, for 3 months commenced from May to July 2017.

\section{Cattle Grouping}

The cows being studied was first weighed to find out initial body weight. The weighing used an electronic scale with sonic scala AE12 brand, the capacity of $2000 \mathrm{~kg}$ x $0.5 \mathrm{~kg}$. Twelve cows were divided into 3 groups based on body weight. Cows with similar body weight were located in one group and one group consisted of 4 cows. Therefore 3 cattle groups were formed with different initial body weight. Each group got treatment, and cow within the group was randomized to get treatment.

\section{Administration of Ration and Drinking Water}

Ration administration was adjusted with each treatment namely, treatment $A$ was given only spear grass and rosewood leaves, treatment $B$ was given treatment $A+10 \%$ falcata tree leaves, treatment $C$ was given treatment $A+15 \%$ falcata tree leaves and treatment $D$ was given treatment $A+20 \%$ falcata tree leaves. Administration of spear grass and rosewood leaves was carried out by ad libitum. Administration of drinking water was carried out after administration of spear grass, rosewood leaves, and falcata tree leaves.

\section{Ration Sampling and Analysis Procedure}

Sampling was carried out for 7 days, in the final week of study. The sample taken was: feces, spear grass, falcata tree leaves and remains of spear grass and falcata tree leaves. Spear grass, falcata tree leaves and remains of spear grass and falcata tree leaves each was taken by $200 \mathrm{~g}$ every day. At the end of taking, the total material was mixed and composited according to the cattle. After being mixed, $200 \mathrm{~g}$ was taken to be analyzed in Laboratory. The taking of feces was as follows: Feces being secreted within 24 hours was collected and weighed to find out its weight. Later feces was taken about $200 \mathrm{~g}$ and dried in sunlight. At the end of taking, a total of feces was mixed and composited according to the cattle, later feces of each cow was taken about $200 \mathrm{~g}$ to be analyzed in the laboratory. A sample of ration and feces was analyzed with proximate analysis for namely, dry ingredients (BK), organic material (BO), crude protein (PK), crude fiber (SK) and gross energy content (GE). These data would be used to calculate dry ingredients digestion (KCBK), and ration nutrient digestion (crude protein, organic material, crude fiber, crude fat).

Sio, S., Sikone, H., \& Usboko, C. (2018). Nutrient digestion and body weight gain of Balinese cows getting basic ration of spear grass and rosewood leaves supplemented with falcata tree leaves. International Journal Of Life Sciences (IJLS), 2(2), 1-11. doi:10.29332/ijls.v2n2.114 


\section{Variables}

Variables being observed including:

1) Ration Nutrient Digestion including Digestion of crude fiber, digestion of organic material and gross energy consumption, which is calculated with the formula of Amount of consumption multiplied by the percentage of dried ration material multiplied by the percentage of ration nutrient.

2) Daily Cattle Weight Gain could be calculated with the formula of Final Weight (kg) reduced by Initial Weight (kg) divided by Duration of Study (days).

\section{Data Analysis}

The data obtained were analyzed with Analysis of Variance. If there was a treatment which differed significantly $(\mathrm{P}<0.05)$, the analysis was continued with Duncan's Multiple Range Test in the level of 5\% (Steel and Torrie, 1986).

\section{Results and Analysis}

\subsection{Dry Ingredients Digestion}

Digestion of dry ingredients by Balinese cows getting ration A was $26.10 \%$. Digestion of dry ingredients by cows getting ration $\mathrm{B}, \mathrm{C}$ and $\mathrm{D}$ were $48.7 \%, 62.5 \%$, and $72.1 \%$, respectively. The result of the study showed that dry ingredients digestion on treatments getting supplementation of falcata tree leaves (treatment $\mathrm{B}, \mathrm{C}$, and $\mathrm{D}$ ) markedly different $(\mathrm{P}<0.05)$ compared to treatment which was not getting falcata tree leaves (treatment $A$ ). The result of Duncan's multiple range test showed real difference between treatment A compared to treatment B, C and D. Treatment B differed significantly with treatment C and D, so did between $\mathrm{C}$ and $\mathrm{D}$. The highest dry ingredients digestion was on treatment $\mathrm{D}$, it was because of high crude protein content on treatment $\mathrm{D}$. The increase of crude protein in treatment $\mathrm{D}$, was able to improve activities of rumen microbes, degraded the feed so that the product of rumen metabolites (VFA and N-NH${ }_{3}$ ) being produced was increasing (Table 1 ).

The average of crude protein digestion of Balinese cows getting ration A was 30\%, and cows getting ration B, C and D were 63\%, 71\%, and 82\%, respectively. The result of Duncan's multiple range test showed protein digestion on treatment which getting falcata tree leaves differed significantly compared to treatment A. Treatment B and C statistically did not differ significantly, but with treatment D it did $(\mathrm{P}<0.05)$ in increasing crude protein digestion. Treatment $\mathrm{C}$ and $\mathrm{D}$ statistically differed significantly $(\mathrm{P}<0.05)$. The highest crude protein digestion was in treatment $\mathrm{D}$ at $82 \%$.

Table 1

Nutrient Digestion of Balinese Cows

\begin{tabular}{|c|c|c|c|c|c|}
\hline \multirow{2}{*}{ Variables } & \multicolumn{4}{|c|}{ Treatment } & \multirow{2}{*}{ SEM } \\
\hline & A & B & $\mathrm{C}$ & $\mathrm{D}$ & \\
\hline Dry Ingredients (\%) & $26.10^{a}$ & $48.7^{b}$ & $62.5^{b}$ & $72.1^{\mathrm{a}}$ & 2.3 \\
\hline Crude Protein (\%) & $30^{\mathrm{b}}$ & $63^{\mathrm{ab}}$ & $71^{\mathrm{b}}$ & $82^{\mathrm{a}}$ & 2.6 \\
\hline Crude Fiber (\%) & $30.23^{\mathrm{b}}$ & $43^{b}$ & $58.3^{\mathrm{b}}$ & $69^{a}$ & 2.01 \\
\hline Organic Matter (\%) & $45^{\mathrm{b}}$ & $65^{b}$ & $72^{\mathrm{a}}$ & $78^{\mathrm{a}}$ & 2 \\
\hline
\end{tabular}

\section{Notes:}

- Value with different superscript in the same row is markedly different $(\mathrm{P}<0.05)$

- $\mathrm{A}=$ ration without falcata tree leaves

- $\mathrm{B}=$ ration with $10 \%$ falcata tree leaves

- $\mathrm{C}=$ ration with $15 \%$ falcata tree leaves

- D = ration with $20 \%$ falcata tree leaves

The addition of falcata tree leaves in basic ration was able to increase ration nutrient, therefore the bacteria was optimal for increasing feed utilization. Bacteria would work more actively in digesting feed inside the rumen, therefore feed digestion would increase. The increase of feed digestion would be 
followed with the height of protein digestion, resulted in the increase of growth and daily weight gain of Balinese cows.

The average of crude fiber digestion in Balinese cows getting ration A was $30.23 \%$. Crude fiber digestion of cows getting ration B, C and D were $43 \%, 58.3 \%$, and $69 \%$, respectively. Result of study showed crude fiber digestion on cows getting treatment with falcata tree leaves differed significantly $(\mathrm{P}<0.05)$ to increase compared to treatment $\mathrm{A}$. The result of Duncan's multiple range test indicated that there was a real difference between treatment A with treatment B, C and D. Treatment B with C and D was obvious, so did treatment $\mathrm{C}$ with $\mathrm{D}$. The highest crude fiber digestion was in treatment $\mathrm{D}$ at $69 \%$. The height of crude fiber digestion in treatment $\mathrm{D}$ was associated with the high content of feed nutrient especially protein, therefore causing the bacterial population to increase. The rise of the bacterial population could also increase its activities to digest feed to produce rumen metabolites (acetic acid, butyrate acid, propionate acid), as a source of energy for cattle. The higher the energy being absorbed could affect the increasing of crude fiber digestion.

\subsection{Synthesis of Microbial Protein}

The average of protein synthesis of rumen microbes in cows getting ration A was $273 \mathrm{~g} / \mathrm{e} / \mathrm{h}$. Cows which getting ration B was $457 \mathrm{~g} / \mathrm{h}, \mathrm{C}$ was $540 \mathrm{~g} / \mathrm{h}$ and D was $589 \mathrm{~g} / \mathrm{h}$. Utilization of falcata tree leaves led to a real increase $(\mathrm{P}<0.05)$ to protein synthesis of rumen microbes. The result of Duncan's multiple range test showed the real difference between treatment getting falcata tree leaves with treatment without falcata tree leaves. Treatment B with C and D was obvious, but between treatment C and D was not (Table 2).

The highest microbial protein synthesis was on treatment D at $589 \mathrm{~g} / \mathrm{e} / \mathrm{h}$ and the lowest was on treatment $A$ at $273 \mathrm{~g} / \mathrm{h}$. The height of microbial protein synthesis on treatment D was associated with supplementation of falcata tree leaves by $20 \%$ which able to improve ration nutrient consumption particularly dry ingredients and protein (Table 1). Crude protein consumption in treatment D was able to increase rumen microbial activities to degrade feed (Table 2), producing high rumen microbial protein synthesis (Table 2). The higher rumen microbial protein synthesis was, resulting in high body weight gain (Table 5).

Table 2

Rumen Microbial Protein Synthesis of Balinese Cows

\begin{tabular}{lccccc}
\hline \multirow{2}{*}{ Variables } & \multicolumn{4}{c}{ Treatment } & \multirow{2}{*}{ SEM } \\
\cline { 2 - 5 } & $\mathrm{A}$ & $\mathrm{B}$ & $\mathrm{C}$ & $\mathrm{D}$ & 0.09 \\
DOMR (g/e/h) & $1.37^{\mathrm{b}}$ & $2.28^{\mathrm{b}}$ & $2.70^{\mathrm{a}}$ & $2.95^{\mathrm{a}}$ & 0.03 \\
Microbial N (g/e/h) & $43.3^{\mathrm{b}}$ & $73.07^{\mathrm{b}}$ & $86.37^{\mathrm{b}}$ & $94.27^{\mathrm{a}}$ & 18.61 \\
SPM (g/e/h) & $273^{\mathrm{b}}$ & $457^{\mathrm{b}}$ & $540^{\mathrm{a}}$ & $589^{\mathrm{a}}$ & 0.05 \\
Purine absorption (mMol/h) & $31.79^{\mathrm{b}}$ & $53.12^{\mathrm{b}}$ & $62.79^{\mathrm{b}}$ & $68.53^{\mathrm{a}}$ & 0. \\
\hline
\end{tabular}

Notes:

- Value with different superscript in the same row is markedly different $(\mathrm{P}<0.05)$

- $\mathrm{A}=$ ration without falcata tree leaves

- $\mathrm{B}=$ ration with $10 \%$ falcata tree leaves

- $\mathrm{C}=$ ration with $15 \%$ falcata tree leaves

- $\mathrm{D}=$ ration with $20 \%$ falcata tree leaves

\subsection{Nutrient Balance Sheet}

The average digested protein by cows getting ration A was $0.14 \mathrm{~kg} / \mathrm{e} / \mathrm{h}$. Cows getting ration $\mathrm{B}, \mathrm{C}$ and D were $0.37 \mathrm{~kg} / \mathrm{e} / \mathrm{h}, 0.45 \mathrm{~kg} / \mathrm{e} / \mathrm{h}$ and $0.55 \mathrm{~kg} / \mathrm{e} / \mathrm{h}$, respectively. Result of variance analysis indicated that ration with falcata tree leaves was obvious $(\mathrm{P}<0.05)$ to increase digested protein compared to treatment $\mathrm{A}$. Result of Duncan's multiple range test showed that on treatment $B, C$ and $D$ were obvious $(P<0.05)$ to increase digested protein compared to treatment $\mathrm{A}$. Treatment between $\mathrm{B}$ and $\mathrm{C}$ was obvious, but between

Sio, S., Sikone, H., \& Usboko, C. (2018). Nutrient digestion and body weight gain of Balinese cows getting basic ration of spear grass and rosewood leaves supplemented with falcata tree leaves. International Journal Of Life Sciences (IJLS), 2(2), 1-11. doi:10.29332/ijls.v2n2.114 
$\mathrm{B}$ and $\mathrm{D}$ was not. Meanwhile, treatment between $\mathrm{C}$ and $\mathrm{D}$ was not obvious. The highest of average digested protein was on cows getting ration treatment $\mathrm{D}$ at $0.55 \mathrm{~kg} / \mathrm{e} / \mathrm{h}$ (Table 3 ).

Table 3

Nutrient Balance Sheet of Balinese Cows

\begin{tabular}{lccccc}
\hline \multirow{2}{*}{ Variables } & \multicolumn{4}{c}{ Treatment } & \multirow{2}{*}{ SEM } \\
\cline { 2 - 5 } & $\mathrm{A}$ & $\mathrm{B}$ & $\mathrm{C}$ & $\mathrm{D}$ & \\
\hline Consumption of Crude Protein $(\mathrm{kg} / \mathrm{e} / \mathrm{h})$ & $0.48^{\mathrm{b}}$ & $0.58^{\mathrm{b}}$ & $0.63^{\mathrm{b}}$ & $0.67^{\mathrm{a}}$ & 0.01 \\
Protein of Feces $(\mathrm{kg} / \mathrm{e} / \mathrm{h})$ & $0.34^{\mathrm{a}}$ & $0.21^{\mathrm{b}}$ & $0.18^{\mathrm{ab}}$ & $0.12^{\mathrm{b}}$ & 0.01 \\
Digested Protein $(\mathrm{kg} / \mathrm{e} / \mathrm{h})$ & $0.14^{\mathrm{b}}$ & $0.37^{\mathrm{b}}$ & $0.45^{\mathrm{b}}$ & $0.55^{\mathrm{a}}$ & 0.06 \\
Consumption of Organic matter $(\mathrm{kg} / \mathrm{e} / \mathrm{h})$ & $4.65^{\mathrm{b}}$ & $5.44^{\mathrm{ab}}$ & $5.74^{\mathrm{a}}$ & $5.81^{\mathrm{a}}$ & 0.10 \\
Organic matter of Feces $(\mathrm{kg} / \mathrm{e} / \mathrm{h})$ & $2.54^{\mathrm{a}}$ & $1.92^{\mathrm{a}}$ & $1.61^{\mathrm{a}}$ & $1.26^{\mathrm{a}}$ & 1.03 \\
Digested Organic matter $(\mathrm{kg} / \mathrm{e} / \mathrm{h})$ & $2.11^{\mathrm{b}}$ & $3.52^{\mathrm{b}}$ & $4.13^{\mathrm{b}}$ & $4.55^{\mathrm{a}}$ & 0.07 \\
Consumption of Crude Fiber $(\mathrm{kg} / \mathrm{e} / \mathrm{h})$ & $0.90^{\mathrm{b}}$ & $1.03^{\mathrm{a}}$ & $1.07^{\mathrm{a}}$ & $1.11^{\mathrm{a}}$ & 0.03 \\
Crude Fiber of Feces $(\mathrm{kg} / \mathrm{e} / \mathrm{h})$ & $0.60^{\mathrm{a}}$ & $0.57^{\mathrm{a}}$ & $0.45^{\mathrm{b}}$ & $0.33^{\mathrm{b}}$ & 0.02 \\
Digested Crude Fiber $(\mathrm{kg} / \mathrm{e} / \mathrm{h})$ & $0.30^{\mathrm{b}}$ & $0.46^{\mathrm{b}}$ & $0.62^{\mathrm{b}}$ & $0.78^{\mathrm{a}}$ & 0.04 \\
\hline
\end{tabular}

Notes:

- Value with different superscript in the same row is obviously different $(\mathrm{P}<0.05)$

- $\mathrm{A}=$ ration without falcata tree leaves

- $\mathrm{B}=$ ration with $10 \%$ falcata tree leaves

- $\mathrm{C}=$ ration with $15 \%$ falcata tree leaves

- D = ration with $20 \%$ falcata tree leaves

The average of the digested crude fiber of Balinese cows getting ration A was $0.30 \mathrm{~kg} / \mathrm{e} / \mathrm{h}$. Cows getting ration $B, C$ and $D$ were $0.46 \mathrm{~kg} / \mathrm{e} / \mathrm{h}, 0.62 \mathrm{~kg} / \mathrm{e} / \mathrm{h}$ and $0.78 \mathrm{~kg} / \mathrm{e} / \mathrm{h}$, respectively. Result of study showed that treatment $B, C$ and $D$ statistically were obvious $(\mathrm{P}<0.05)$ to improve digested crude fiber compared to treatment A. Duncan's multiple range tests showed that digested crude fiber in treatment A statistically differed significantly $(\mathrm{P}<0.05)$ with treatment $\mathrm{B}, \mathrm{C}$ and $\mathrm{D}$. Treatment $\mathrm{B}$ with $\mathrm{C}$ and $\mathrm{D}$ was obvious, but between $\mathrm{C}$ and $\mathrm{D}$ was not obvious statistically. The highest digested crude fiber was on cows getting ration $\mathrm{D}$ at $0.78 \mathrm{~kg} / \mathrm{e} / \mathrm{h}$. The height of digested crude fiber on treatment $\mathrm{D}$ was associated with formulated ration which containing appropriate crude protein content for requirements of rumen microorganism so that it was able to improve crude fiber digestion which had an effect on the increase of digested crude fiber.

Table 4

Energy Balance Sheet of Balinese Cows

\begin{tabular}{|c|c|c|c|c|c|}
\hline \multirow{2}{*}{ Variables } & \multicolumn{4}{|c|}{ Treatment } & \multirow{2}{*}{ SEM } \\
\hline & A & B & $\mathrm{C}$ & D & \\
\hline Consumption of Energy $(\mathrm{kcal} / \mathrm{e} / \mathrm{h})$ & $16593^{b}$ & $17859^{\mathrm{b}}$ & $20249^{a}$ & $21656^{\mathrm{a}}$ & 0.09 \\
\hline Energy of Feces $(\mathrm{kcal} / \mathrm{e} / \mathrm{h})$ & 11389.72 & 8661.07 & 7339.12 & 5801.13 & 0.08 \\
\hline Digested Energy (kcal/e/h) & $5203.3^{\mathrm{b}}$ & $9197.9^{b}$ & $12909.9^{b}$ & $15854.9^{a}$ & 0.06 \\
\hline
\end{tabular}

Notes:

- Value with different superscript in the same row is obviously different $(\mathrm{P}<0.05)$

- $\mathrm{A}=$ ration without falcata tree leaves

- $\mathrm{B}=$ ration with falcata tree leaves of $10 \%$

- $\mathrm{C}=$ ration with falcata tree leaves of $15 \%$

- $D=$ ration with falcata tree leaves of $20 \%$ 


\subsection{Body Weight Gain}

The initial weight of Balinese cows getting ration without falcate tree leaves (A) was: $128.6 \mathrm{~kg}$. Cows which getting ration B, C and D were: $128.3 \mathrm{~kg}, 129 \mathrm{~kg}$ and $129 \mathrm{~kg}$, respectively. The result of variance analysis showed that there was not any significant difference $(P>0.05)$ between all treatments.

The final weight of Balinese cows getting control ration (A) was: $153.7 \mathrm{~kg}$. Cows getting ration B, C and D were: $161.3 \mathrm{~kg}, 171.3 \mathrm{~kg}$ and $181 \mathrm{~kg}$, respectively. The result of variance analysis showed that there was not any significant difference $(P>0.05)$ between all treatments, although, in treatment $B, C$ and $D$ final weight of the cows were higher than cows getting treatment $A$.

Weight gain during the study by cows getting ration A (control) was: $25 \mathrm{~kg}$. Cows getting ration B, C and D were: $33 \mathrm{~kg}, 42.3 \mathrm{~kg}$ and $52 \mathrm{~kg}$, respectively. The result of analysis of variance showed that cows getting ration $B, C$ and $D$ were statistically obvious $(\mathrm{P}<0.05)$ in increasing weight gain compared to cows getting control ration (A). The result of Duncan's multiple range test had indicated that cows getting ration $\mathrm{B}, \mathrm{C}$ and $\mathrm{D}$ had its weight gain differed significantly $(\mathrm{P}<0.05)$ to increase compared to cows getting control ration. Treatment $\mathrm{B}$ with $\mathrm{C}$ and $\mathrm{D}$ was obvious, meanwhile, treatment between $\mathrm{C}$ and $\mathrm{D}$ was not obvious statistically (Table 5).

Daily weight gain of Balinese cows getting ration A was: $0.31 \mathrm{~kg} / \mathrm{e} / \mathrm{h}$, cows getting ration $\mathrm{B}, \mathrm{C}$ and D were: $0.41 \mathrm{~kg} / \mathrm{e} / \mathrm{h}, 0.53 \mathrm{~kg} / \mathrm{e} / \mathrm{h}$ and $0.65 \mathrm{~kg} / \mathrm{e} / \mathrm{h}$, respectively (Table 5 ). The result of variance analysis showed that daily weight gain of Balinese cows getting ration with falcata tree leaves statistically differed significantly $(\mathrm{P}<0.05)$ to increase compared to treatment without getting falcata tree leaves. The result of Duncan's multiple range test showed that treatment getting falcata tree leaves was statistically obvious $(\mathrm{P}<0.05)$ in increasing daily weight gain compared to cows getting ration without falcata tree leaves. Treatment between B and C was not obvious but with D it was obvious, meanwhile, treatment between $\mathrm{C}$ and D did not differ significantly.

Lowest daily weight gain was on Balinese cows getting ration $\mathrm{A}$ (control) at $0.31 \mathrm{~kg} / \mathrm{e} / \mathrm{h}$ and highest daily weight gain was on cows getting ration $\mathrm{D}$ at $0.65 \mathrm{~kg} / \mathrm{e} / \mathrm{h}$, followed by cows getting ration C: 0.53 $\mathrm{kg} / \mathrm{e} / \mathrm{h}$ and cows getting ration $\mathrm{B}$ at $0.41 \mathrm{~kg} / \mathrm{e} / \mathrm{h}$.

Balinese cows getting ration D produced highest weight gain at $0.65 \mathrm{~kg} / \mathrm{e} / \mathrm{h}$. It had indicated that ration which being formulated had appropriate nutrient content and suitable for the needs of cattle's physiologic. Ration with high crude protein content was able to improve bacterial activity so that it was able to increase feed digestion which capable to produce rumen metabolites that is utilized to increase the growth followed by the height of daily weight gain of cows which getting $20 \%$ of falcata tree leaves.

Duncan's multiple range test showed that FCR scores on cows getting ration B, C and D statistically differed significantly compared to cows getting ration A. Treatment between B and C were not obvious but with D it was obvious. Meanwhile between C and D was not obvious statistically (Table 5). The lowest feed conversion ratio score in this research was on Balinese cows getting treatment $\mathrm{D}$ at 7.9. Cows getting a basic ration of spear grass and rosewood leaves supplemented with $20 \%$ falcata tree leaves became more efficient in transforming ration to increase weight gain. It was seen on cows getting treatment $\mathrm{D}$, their weight gain was greater at $0.65 \mathrm{~kg} / \mathrm{e} / \mathrm{h}$ with lower FCR score at 7.9 (Table 5).

Table 5

The appearance of Balinese cows

\begin{tabular}{|c|c|c|c|c|c|}
\hline \multirow{2}{*}{ Variables } & \multicolumn{4}{|c|}{ Treatment } & \multirow{2}{*}{ SEM } \\
\hline & $\mathrm{A}$ & $\mathrm{B}$ & $\mathrm{C}$ & $\mathrm{D}$ & \\
\hline Initial Body Weight (kg) & $128.6^{\mathrm{a}}$ & $128.3^{b}$ & $129^{a}$ & $129^{a}$ & 1.44 \\
\hline Final Body Weight (kg) & $153.7^{\mathrm{a}}$ & $161.3^{a}$ & $171.3^{\mathrm{a}}$ & $181^{\mathrm{a}}$ & 23.14 \\
\hline PBB (kg) & $25^{b}$ & $33^{b}$ & $42.3^{b}$ & $52^{\mathrm{b}}$ & 0.99 \\
\hline PBB $(\mathrm{kg} / \mathrm{e} / \mathrm{h})$ & $0.31^{\mathrm{b}}$ & $0.41^{\mathrm{b}}$ & $0.53^{\mathrm{b}}$ & $0.65^{\mathrm{a}}$ & 0.01 \\
\hline FCR & $12.6^{\mathrm{a}}$ & $10.3^{\mathrm{b}}$ & $9.0^{\mathrm{ab}}$ & $7.9^{\mathrm{ab}}$ & 0.6 \\
\hline
\end{tabular}

Notes:

- Value with different superscript in the same row is obviously different $(\mathrm{P}<0.05)$

Sio, S., Sikone, H., \& Usboko, C. (2018). Nutrient digestion and body weight gain of Balinese cows getting basic ration of spear grass and rosewood leaves supplemented with falcata tree leaves. International Journal Of Life 
- $A=$ ration without falcata tree leaves

- $B=$ ration with $10 \%$ falcata tree leaves

- $\mathrm{C}=$ ration with $15 \%$ falcata tree leaves

- D = ration with $20 \%$ falcata tree leaves

\section{Conclusion}

From the result of the study it can be concluded that administration of falcate tree leaves in basic ration consisted of spear grass and rosewood leaves are able to increase nutrient digestion, therefore bacteria is optimal in increasing feed utilization and leads to a high weight gain of Balinese cows.

\section{Conflict of interest statement and funding sources}

The authors declared that they have no competing interest. The study was financed by private.

\section{Statement of authorship}

The authors have a responsibility for the conception and design of the study. The authors have approved the final article.

\section{Acknowledgments}

Our deep and sincere gratitude were presented to God for having granted us the ability and the opportunity to complete this paper. We would also like to thank our former lecturers and our friends for their support, their patience, their contribution, and their valuable input, therefore, this article could be completed. We would also thank I Wayan Suryasa (Scopus ID) as an advisor as well as editor in chief of ScienceScholar who has reviewed and approved this study to be published. 


\section{References}

1. Cakra, I. G. L. O. (2013). The role of lime urea in concentrate containing cassava toward rumen's performance and growth of Etawah crossbreed goat. Dissertation. Denpasar. Post graduate program of Udayana University.

View in (Google)

2. Calabro, S. R. (1962). Reliability principles and practices. McGraw-Hill.

View in (Google Scholar)

3. Cattle, G. O. B. Protein And Energy Requirement For Maintenance.

View in (Google Scholar)

4. Dewi, N. N. A., \& Mustika, I. W. (2018). Nutrition Content and Antioxidant Activity of Black Garlic. International Journal of Health Sciences (IJHS), 2(1), 11-20.

View in (Google Scholar)

5. Kearl, L. C. (1982). Nutrient requirements of ruminants in developing countries. International Feedstuffs Institute.

View in (Google Scholar)

6. Leburaya, F. (2012). Implication of Climate change toward management of regional development. National - international seminar, Dies Natalis X, Timor University, at Kefamenanu, January 21 2012.

View in (Article)

7. Mariani, N. P. (2013). Response of Balinese ox toward administration of ration with different protein and energy and its relationship with protein and energy requirements. Dissertation. Denpasar : Post graduate program of Udayana University.

View in (Article)

8. Ogu, G. I., \& Orjiakor, P. I. (2017). Microbiological and Nutritional Qualities of Fermented Melon Seed Shells. International Journal of Life Sciences (IJLS), 1(2), 1-9.

View in (Google Scholar)

9. Oka, I. G. L., Suyadnya, I. P., Putra S., Suarna, I. M., Suparta, I. N. (2012). Balinese cows as genuine Indonesian genetic resources. Center of Study for Balinese cows, Udayana University. Udayana University Press. Denpasar.

View in (Google Scholar)

10. Parakkasi, A. (1999). Ilmu nutrisi dan makanan ternak ruminan. Penerbit Universitas Indonesia, Jakarta. View in (Google Scholar)

11. Saxena, A. (2017). The Impact of Nutrition on the Overall Quality of Life Adolescent Girls are Living Across the City of Kota. International Journal of Life Sciences (IJLS), 1(1), 40-48.

View in (Google Scholar)

12.Sio, S. (2016). Usage of stewed water of Indian ash tree peel (Lannea coromandelica) to increase the growth of Balinese ox. Dissertation. Post graduate program, Udayana University, Denpasar, Bali.

View in (Article)

Sio, S., Sikone, H., \& Usboko, C. (2018). Nutrient digestion and body weight gain of Balinese cows getting basic ration of spear grass and rosewood leaves supplemented with falcata tree leaves. International Journal Of Life Sciences (IJLS), 2(2), 1-11. doi:10.29332/ijls.v2n2.114 
13. Stefanus, S., Mahardika, I. G., Partama, I. B. G., \& Suryani, N. N. Rumen Metabolite of Balinese Cows that Being Given Stewed Water of Lannea coromandelica Peel as Feed Additive.Journal of College and University. This is an open access article under the, 2454, 2261.

View in (Google Scholar)

14. Stefanus, S., Mahardika, I. G., Partama, I. B. G., \& Suryani, N. N. Rumen Metabolite of Balinese Cows that Being Given Stewed Water of Lannea coromandelica Peel as Feed Additive.Journal of College and University. This is an open access article under the, 2454, 2261.

View in (Google Scholar) 


\section{Biography of Author}

\begin{tabular}{|l|l||}
\hline \hline & $\begin{array}{l}\text { Ir. Stefanus Sio, M.P. is a civil servant with registration number 196712312003121003. } \\
\text { He Has been a lector in Faculty of agriculture, Timor University, Kefamenanu, NTT. In } \\
\text { 1992, he had finished his bachelor of degree at faculty of animal husbandry in } \\
\text { University of Nusa Cendana Kupang. In 2010, he had completed his master degree at } \\
\text { study program in animal husbandry, Pascasarjana Udayana University Denpasar } \\
\text { Indonesia. Now, he is a student of a doctorate program at the University of Udayana. He } \\
\text { therefore on completing his dissertation to get a doctorate degree. } \\
\text { Email: stefsio67@ gmail.com }\end{array}$ \\
\hline
\end{tabular}

Sio, S., Sikone, H., \& Usboko, C. (2018). Nutrient digestion and body weight gain of Balinese cows getting basic ration of spear grass and rosewood leaves supplemented with falcata tree leaves. International Journal Of Life Sciences (IJLS), 2(2), 1-11. doi:10.29332/ijls.v2n2.114 